\title{
Phytophilous cladocerans (Crustacea, Anomopoda and Ctenopoda) from Paranã River Valley, Goiás, Brazil
}

\author{
Lourdes M. A. Elmoor-Loureiro
}

Laboratório de Zoologia, Universidade Católica de Brasília. QS 7 lote 1, Bloco M, sala 331, 71966-700 Taguatinga, Distrito

Federal, Brasil.E-mail: lourdes@ucb.br

\begin{abstract}
A rapid assessment survey identified 39 phytophilous cladocerans species from littoral zones of rivers, permanent and temporary lagoons, and swamps of the Paranã River Valley, Goiás, Brazil, 22 are registered for the first time in Central Brazil. Aspects of the taxonomy of some of these species are discussed. Cluster analysis (UPGMA) revealed two phytophilous cladoceran assemblages, characterized by higher or lower richness and relative abundance of species of the families Daphniidae and Moinidae (filter feeders), in comparison with the dominant families Chydoridae and Macrothricidae (scraper feeders).

KEY WORDS. Cladocera; cluster analysis; phytophilous fauna; species richness.
\end{abstract}

\begin{abstract}
RESUMO. Cladóceros fitófilos (Crustacea, Anomopoda and Ctenopoda) do vale do Rio Paranã, Goiás, Brasil. Através de amostragens rápidas, levantou-se as espécies de cladóceros fitófilos presentes em zonas litorâneas de rios, lagoas e brejos permanentes e temporários do vale do Rio Paranã, Goiás, Brasil. Foram encontradas 39 espécies, das quais 22 são registradas pela primeira vez na região central do Brasil. São discutidos aspectos da taxonomia de algumas dessas espécies. A análise de agrupamento (UPGMA) dos pontos de amostragem mostrou dois tipos de associações de espécies de cladóceros fitófilos, caracterizadas pela maior ou menor riqueza e abundância relativa das espécies das famílias Daphniidae e Moinidae (filtradoras), em contraste com as famílias dominantes Chydoridae e Macrothricidae, tipicamente raspadoras do substrato.
\end{abstract}

PALAVRAS-CHAVE. Análise agrupamento; Cladocera; fauna fitófila; riqueza de espécies.

Marginal zones of lentic or lotic environments, as well as swampy environments, are considered ecotones between terrestrial and aquatic environments, being characterized by communities marked by the presence of aquatic macrophytes. The submerged parts of macrophytes provides substrates for the development of periphyton, which acts as food resource and support a complex community of aquatic invertebrates (TAKEDA et al. 2003). This phytophilous fauna has been the focus of growing attention, as the comprehension of its role in the energy flow of aquatic ecosystems increases. The importance of this community in water quality evaluation is high, considering that marginal zone of aquatic environments has been subject to extensive morphological modifications deriving from human activities (MARGARITORA et al. 2003).

The water-land ecotone regions usually present a higher species richness than the open water environments. The higher complexity of microenvironments, generated by the presence of several species of macrophytes, seems to be the factor responsible for this increase in richness (NogueIra et al. 2003).

Cladocerans comprise a major part of the diverse littoral community (Dodson \& Frey 2001). Littoral species include truly filter feeders, such as some sidids (Ctenopoda) and some moinids and daphniids (Anomopoda Sars, 1865), as well scraper feeders, such as macrothricids and chydorids (Anomopoda). In the later case, animals typically feed by crawling along surfaces or through mud and scraping up or filtering food (FRYER 1968, 1974), being specialized in exploring the several microhabitats created by the submerged parts of the macrophytes. It cannot be attributed to a random event the fact that these two families correspond to about $60 \%$ of all known cladoceran species diversity (KoROvCHISNKY 1996).

The Paranã River basin has 5.940.382 ha, and it is a depression between the Central Goiano Plateau and the plateau representing the São Francisco and the Tocantins divide $\left(13^{\circ} 20^{\prime}\right.$ $15^{\circ} 40^{\prime} \mathrm{S}, 46^{\circ} 35^{\prime}-47^{\circ} 30^{\prime} \mathrm{W}$ ) (Silva \& SCARIOT 2003). Like in most parts of the Central Brazilian Plateau, the cladoceran fauna of this region is still unknown (Elmoor-Loureiro 2000).

As part of the PROBIO project "Assessment Survey of the Aquatic Biota with Conservation and Sustainable Use Intent of the Cerrado Biome (Paranã River Mountain Range and Valley)", this study aimed to survey the cladoceran species associated with macrophytes of permanent and temporary freshwater environments of this region. 


\section{MATERIAL AND METHODS}

The Paranã River Basin (Fig. 1) is located in the Central Brazil, and the regional climate has two well-defined periods: a cool, dry winter (from May to September) and a warm, rainy summer (from October to April). Sample collection occurred during rapid sampling expeditions conducted throughout the wet season (2003 and 2005) and, in case of perennial water bodies, also in the dry season (2003 and 2004). Although 30 sampling points were defined for the PROBIO project, for the present work it was selected only the water bodies where an expressive macrophyte community existed or where other appropriate substrates for cladoceran colonization were present (e.g. submerged terrestrial plants) (Tab. I, Figs 2-5).

For specimens sampling, it was used a plankton net with mesh size of $130 \mu \mathrm{m}$, which was large enough to reduce the sediment in the samples, yet small enough to hold adult cladocerans (eventually, the youngest individuals could be lost). The net had its opening protected by a grating $(1 \mathrm{~cm}$ mesh), in order to avoid the introduction of large fragments. The net was introduced among the macrophytes and the filtered content was fixed in $4 \%$ formalin. Animals were sorted and counted under a stereomicroscope. When few specimens were present, entire samples were counted, but when samples were very rich, successive sub-samples were examined until the cumulative richness remained stable (at least five sub-samples without the addition of new taxons). The relative abundance of each taxon was registered, with the intention of identifying the dominant

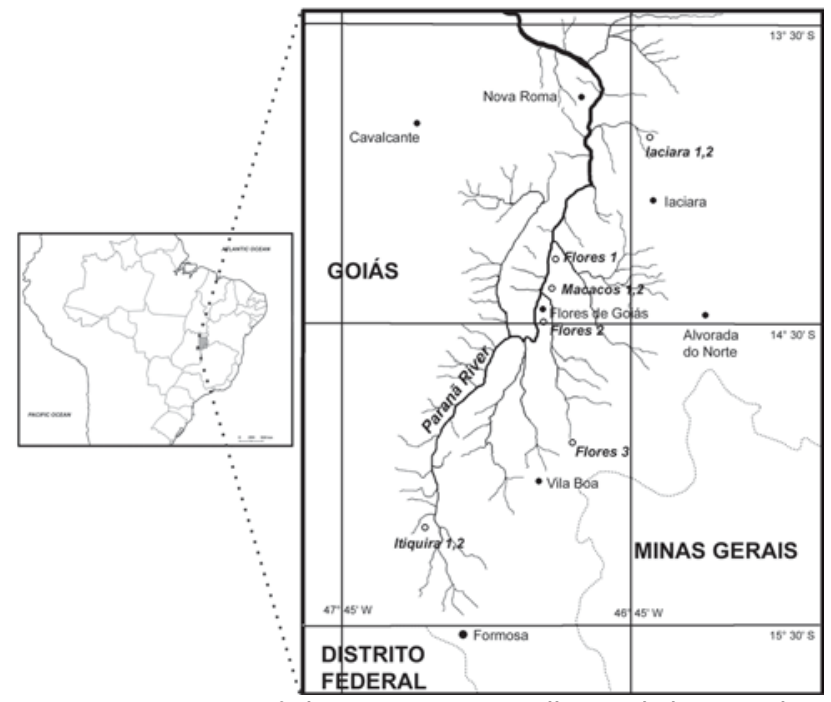

Figure 1. Location of the Paranã River Valley and the sampling points (solid circles).

species (approximately 50\% of the relative abundance). Voucher specimens are deposited at the Laboratory of Zoology of Universidade Católica de Brasília.

In order to compare the cladoceran fauna among the sampling points, a cluster analysis (UPGMA, mean character difference) was conducted using PAUP 4 (SwOFFORD 1999). The data

Table I. Position and characterization of the phytophilous cladoceran sampling points in the Paranã River Valley, Goiás, Brazil.

\begin{tabular}{|c|c|c|c|}
\hline Sampling points & & Coordinates & Type of substrate \\
\hline laciara 1 & $\begin{array}{l}\text { Temporary flood area, road GO110, } \\
\text { laciara County }\end{array}$ & $13^{\circ} 49^{\prime} 35.2^{\prime \prime} \mathrm{S} ; 46^{\circ} 38^{\prime} 54.5^{\prime \prime} \mathrm{W}$ & Dense emergent macrophytes \\
\hline laciara 2 & $\begin{array}{l}\text { Water pond for cattle, } 100 \mathrm{~m} \text { from point } \\
\text { laciara } 1\end{array}$ & $13^{\circ} 49^{\prime} 35.2^{\prime \prime} \mathrm{S} ; 46^{\circ} 38^{\prime} 54.5^{\prime \prime} \mathrm{W}$ & Spaced emergent macrophytes \\
\hline Itiquira 1 & $\begin{array}{l}\text { Natural lagoon with elevated water level } \\
\text { created by a dam, near Salto de Itiquira, } \\
\text { road GO116, Formosa County }\end{array}$ & $15^{\circ} 09^{\prime} 15.8^{\prime \prime S} ; 47^{\circ} 28^{\prime} 04.7^{\prime \prime W}$ & Dense submerged macrophytes \\
\hline Itiquira 2 & $\begin{array}{l}\text { Temporary flood area, between point } \\
\text { Itiquira } 1 \text { and road }\end{array}$ & $15^{\circ} 09^{\prime} 15.8^{\prime \prime S} ; 47^{\circ} 28^{\prime} 04.7^{\prime \prime W}$ & Submerged grass in decomposition \\
\hline Flores 1 & $\begin{array}{l}\text { Temporary swamp between the Macacos } \\
\text { and Correntes Rivers, road GO236, Flores } \\
\text { de Goiás County }\end{array}$ & $14^{\circ} 18^{\prime} 23.9^{\prime \prime S} ; 46^{\circ} 57^{\prime} 34.0^{\prime \prime} \mathrm{W}$ & Emergent and a few floating macrophytes \\
\hline Flores 2 & $\begin{array}{l}\text { Flooded areas along the right (point } \\
\text { Flores } 2 \mathrm{~d} \text { ) and left (point Flores 2e) } \\
\text { margins of road GO114 way to Flores de } \\
\text { Goiás }\end{array}$ & $15^{\circ} 09^{\prime} 15.8^{\prime \prime S} ; 47^{\circ} 28^{\prime} 04.7^{\prime \prime W}$ & Submerged macrophytes \\
\hline Flores 3 & $\begin{array}{l}\text { Natural lagoon, BR020, near the } \\
\text { intersection of road GO114, Flores de } \\
\text { Goiás County }\end{array}$ & $14^{\circ} 54^{\prime} 56.0^{\prime \prime}$; $46^{\circ} 57^{\prime} 02.9^{\prime \prime} \mathrm{W}$ & Submerged and dense floating macrophytes \\
\hline Macacos 1 & Macacos River, Flores de Goiás County & $14^{\circ} 27^{\prime} 42.9^{\prime \prime} \mathrm{S} ; 47^{\circ} 00^{\prime} 15.2^{\prime \prime} \mathrm{W}$ & Spaced grass and phylamentous algae \\
\hline Macacos 2 & $\begin{array}{l}\text { Backwater of Macacos River, Flores de } \\
\text { Goiás County }\end{array}$ & $14^{\circ} 27^{\prime} 42.9^{\prime \prime}$; $47^{\circ} 00^{\prime} 15.2^{\prime \prime} \mathrm{W}$ & Submerged tree limbs and leaves \\
\hline
\end{tabular}




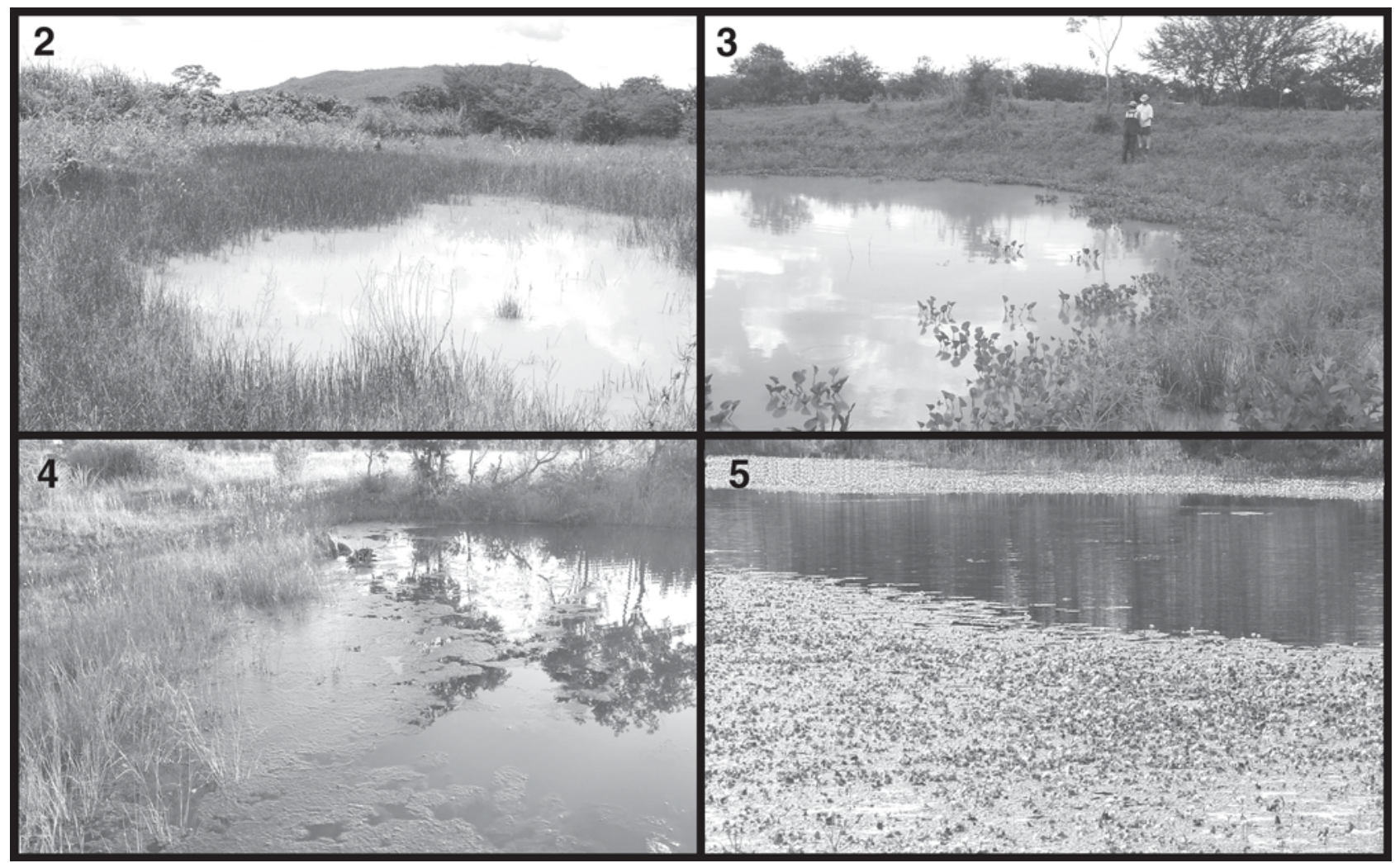

Figures 2-5. General aspects of the phytophilous cladoceran sampling points in water bodies of the Paranã River Valley, with predominant emerged macrophytes (2 - laciara 1; 3 - laciara 2) or submerged macrophytes (4 - Flores 2e; 5 - Flores 3).

matrix was constructed coding for presence (1) and absence (0) of each species in the samples using the software MacClade 3.04 (MADDISON \& MADDISON 1992). For this analysis, data from the sampling repetitions were combined. For perennial water bodies, the Sørensen coefficient was calculated to estimate the similarity between community in dry and wet season.

\section{RESULTS AND DISCUSSION}

A total of 39 cladoceran species were identified (Tab. II), of which 22 were registered for the first time for this region of Central Brazil - Distrito Federal/Goiás (cf. Elmoor-Loureiro 2000, ELMOOR-Loureiro et al. 2004). Since the majority of these species possess an ample distribution, their occurrence in the Brazilian Midwest is predictable. No endemic species to this region were identified.

In the last two decades, several Neotropical species of cladocerans were the object of taxonomical reviews (e.g. Frey 1993, Sinev 1998, 2001a, b, SiLva-Briano et al. 1999, Dumont \& Silva-Briano 2000, Dumont et al. 2002, Котоv et al. 2002), supporting even more the idea that species once considered cosmopolitan, actually represent species complexes (Frey 1995, KorovchinsKy 1996, Dumont 1997). The taxonomy of some of these complexes is not entirely elucidated, being the case of Latonopsis australis-group (KorovchinsKy 1992), Ephemeroporus barroisi-group (Frey 1982) and Simocephalus acutirostratus-group (OrLOVA-BIENKOWSKAJA 2001).

Several species identified in this study were the object of recent reviews, therefore, they were not included in ELMOoRLouREIro (2000), or were presented in different genera. These species are illustrated and aspects of their taxonomy are discussed below.

Alona dentifera (Sars, 1901) (Figs 6 and 7) was originally described in the Alonella genus, but was recently transferred to Alona Baird, 1843, particularly because of its trunk limbs characteristics, which are typically of the Aloninae type (SINEv et al. 2004). These authors, based on the detailed comparisons, also affirm that Alonella brasiliensis Bergamin, 1935 is a junior synonym of $A$. dentifera.

Alona verrucosa Sars, 1901 (Figs 8 and 9), due to the presence of two median cephalic pores, was transferred to the Biapertura Smirnov, 1971. Sinev \& Hollwedel (2002) presented this species once again in the Alona genus, following the tendency to abandon the Biapertura genus, now considered an artificial taxon.

Alonella dadayi Birge, 1910 (Figs 10 and 11) is frequently cited in Brazil, however by different names, sometimes as Dispa-

Revista Brasileira de Zoologia 24 (2): 344-352, junho 2007 
Table II. Cladoceran species from flooded areas and marginal zones of aquatic environments of the Paranã River Valley and mountain range. The first records of occurrence in Central Brazil are indicated by $\left(^{*}\right)$. Species that had a relative abundance close or superior to $50 \%$, characterizing strong community dominance are indicated by (xx). (Flor) Flores, (Itiq) Itiquira, (laci) laciara, (Mac) Macacos.

\begin{tabular}{|c|c|c|c|c|c|c|c|c|c|c|c|c|}
\hline \multirow{2}{*}{ Taxa } & \multicolumn{5}{|c|}{ Wet season 2003} & \multicolumn{2}{|c|}{ Dry season $2003-4$} & \multicolumn{5}{|c|}{ Wet season 2005} \\
\hline & Itiq1 & Itiq2 & Mac1 & Mac2 & Flor1 & Itiq1 & Mac1 & laci1 & laci2 & Flor2d & Flor2e & Flor3 \\
\hline \multicolumn{13}{|l|}{ Ctenopoda } \\
\hline \multicolumn{13}{|l|}{ Sididae Baird, 1850} \\
\hline Diaphanosoma brevireme Sars 1901 & $x$ & $x$ & & & & & $x$ & & $x$ & & & \\
\hline Diaphanosoma spinulosum Herbst, 1967 & & & & & & & & & & $x$ & & \\
\hline Latonopsis australis-group & $x$ & $x$ & & & & $x$ & & & & $x$ & $x$ & $x x$ \\
\hline * Pseudosida ramosa (Daday, 1904) & & & $\mathrm{x}$ & $x$ & & & & & & & $x$ & \\
\hline \multicolumn{13}{|l|}{ Anomopoda } \\
\hline \multicolumn{13}{|l|}{ Daphniidae Straus, 1820} \\
\hline Ceriodaphnia cornuta Sars, 1886 & & & & $x$ & & $x$ & $x$ & $x x$ & $x x$ & & & \\
\hline * Scapholeberis armata (Herrick, 1882) & & & & $x$ & & & & & & & & \\
\hline * Simocephalus acutirostratus-group & & & & $x$ & $x x$ & & & & $x$ & & & \\
\hline * Simocephalus latirostris Stingelin, 1906 & & & $\mathrm{x}$ & & & $\mathrm{x}$ & & & & & & \\
\hline \multicolumn{13}{|l|}{ Moinidae Goulden, 1968} \\
\hline * Moina reticulata (Daday, 1905) & & & & $x$ & & & & & & & & \\
\hline Moina micrura Kurz, 1874 & & & & & & & & & $x$ & & & \\
\hline * Moinodaphnia macleayi (King, 1853) & & $x$ & & $x$ & & & & $x x$ & $x$ & & & \\
\hline \multicolumn{13}{|l|}{ Ilyocryptidae Smirnov, 1992} \\
\hline Ilyocryptus spinifer Herrick, 1882 & $\mathrm{x}$ & $\mathrm{x}$ & $\mathrm{x}$ & $\mathrm{x}$ & & $\mathrm{x}$ & $x$ & & & $x$ & $x$ & $x$ \\
\hline \multicolumn{13}{|l|}{ Macrothricidae Norman \& Brady, 1867} \\
\hline Macrothrix elegans Sars, 1901 & $x$ & $x$ & $x$ & $x$ & $x$ & $x$ & $x$ & & & $x$ & $x$ & $x$ \\
\hline Macrothrix squamosa Sars, 1901 & $x$ & & $x$ & & $x$ & $x$ & $x$ & & & & & \\
\hline Macrothrix paulensis (Sars, 1900) & & & & & & & & & & $\mathrm{x}$ & & \\
\hline Streblocerus pygmaeus Sars, 1901 & $x$ & & & & & & & & & & $x$ & $x$ \\
\hline \multicolumn{13}{|l|}{ Chydoridae Stebbing, 1902} \\
\hline * Alona dentifera (Sars, 1901) & & & & $\mathrm{x}$ & & $\mathrm{x}$ & & & & & & \\
\hline Alona guttata Sars, 1862 & $x$ & & & & & & & & & & & \\
\hline * Alona monacantha Sars, 1901 & & $\mathrm{x}$ & & & & & $x$ & & & & & \\
\hline * Alona ossiani Sinev, 1998 & $\mathrm{x}$ & & & & & & & & & & & \\
\hline * Alona verrucosa Sars, 1901 & $x$ & $x$ & & $x$ & & $x$ & & & & $x$ & $x$ & $x$ \\
\hline Alonella dadayi Birge, 1910 & & $x$ & & & & $x$ & & & & & & $x$ \\
\hline * Chydorus dentifer Daday, 1905 & $\mathrm{x}$ & & & & & $x$ & & & & & $x$ & $x$ \\
\hline Chydorus eurynotus Sars, 1901 & & $x$ & & & & & & & & & & \\
\hline * Chydorus nitidulus (Sars, 1901) & $x$ & $x$ & & & $x$ & $x$ & & & & $x$ & & \\
\hline Chydorus pubescens Sars, 1901 & $x$ & $x$ & $x$ & $x$ & & $x$ & & & & & & $x$ \\
\hline Chydorus sp. & & & & $x$ & & $x$ & & & & & $x$ & \\
\hline * Dadaya macrops (Daday, 1898) & & & & $x$ & $x$ & & & & & & & \\
\hline * Dunhevedia odontoplax Sars, 1901 & & & & & $x$ & & & & & $\mathrm{x}$ & & \\
\hline Ephemeroporus barroisi-group & & $x$ & & & & $x$ & & & & $x$ & $x$ & \\
\hline * Ephemeroporus hybridus (Daday, 1905) & & $x$ & $x$ & $x$ & & & & & & $x$ & $x$ & $x$ \\
\hline * Ephemeroporus tridentatus (Bergamin, 1931) & & & & $x$ & $\mathrm{x}$ & & $x$ & & & $x$ & & \\
\hline Euryalona orientalis (Daday, 1898) & & & & $x$ & & & & & & & & \\
\hline * Graptoleberis occidentalis Sars, 1901 & $x$ & & & & & & & & & & & \\
\hline * Karualona mülleri (Richard, 1897) & $x$ & $x$ & & $\mathrm{x}$ & $x$ & $\mathrm{x}$ & & $x$ & & $x$ & $x$ & \\
\hline${ }^{*}$ Leydigiopsis megalops Sars, 1901 & $x$ & & & $x$ & & $x$ & & & & & & \\
\hline * Nicsmirnovius cf incrediblis (Smirnov, 1984) & & & $x$ & & & & & & & & & \\
\hline * Notalona sculpta (Sars, 1901) & & & & $\mathrm{x}$ & & & & & & & & \\
\hline * Oxyurella longicaudis (Birge, 1910) & & & & & $x$ & & & $x$ & $x$ & & & \\
\hline Number of species & 14 & 15 & 8 & 19 & 9 & 16 & 7 & 4 & 6 & 12 & 11 & 9 \\
\hline
\end{tabular}




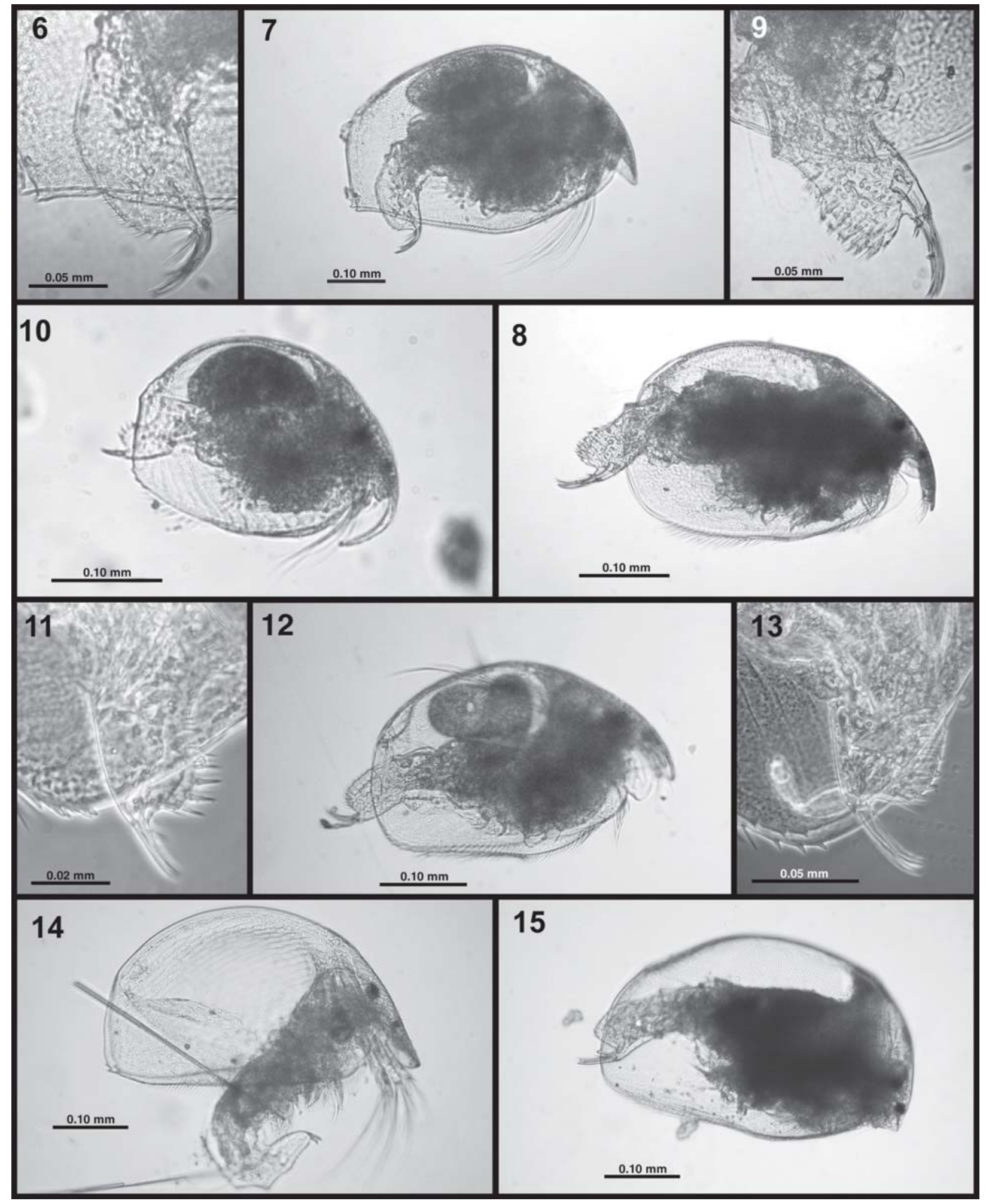

Figures 6-15. Chydoridae cladoceran species found in water bodies in the Paranã River Valley. (6-7) Alona dentifera; (8-9) Alona verrucosa; (10-11) Alonella dadayi; (12-13) Karualona mülleri; (14) Graptoleberis occidentalis; (15) Nicsmirnovius cf incredibilis.

Revista Brasileira de Zoologia 24 (2): 344-352, junho 2007 


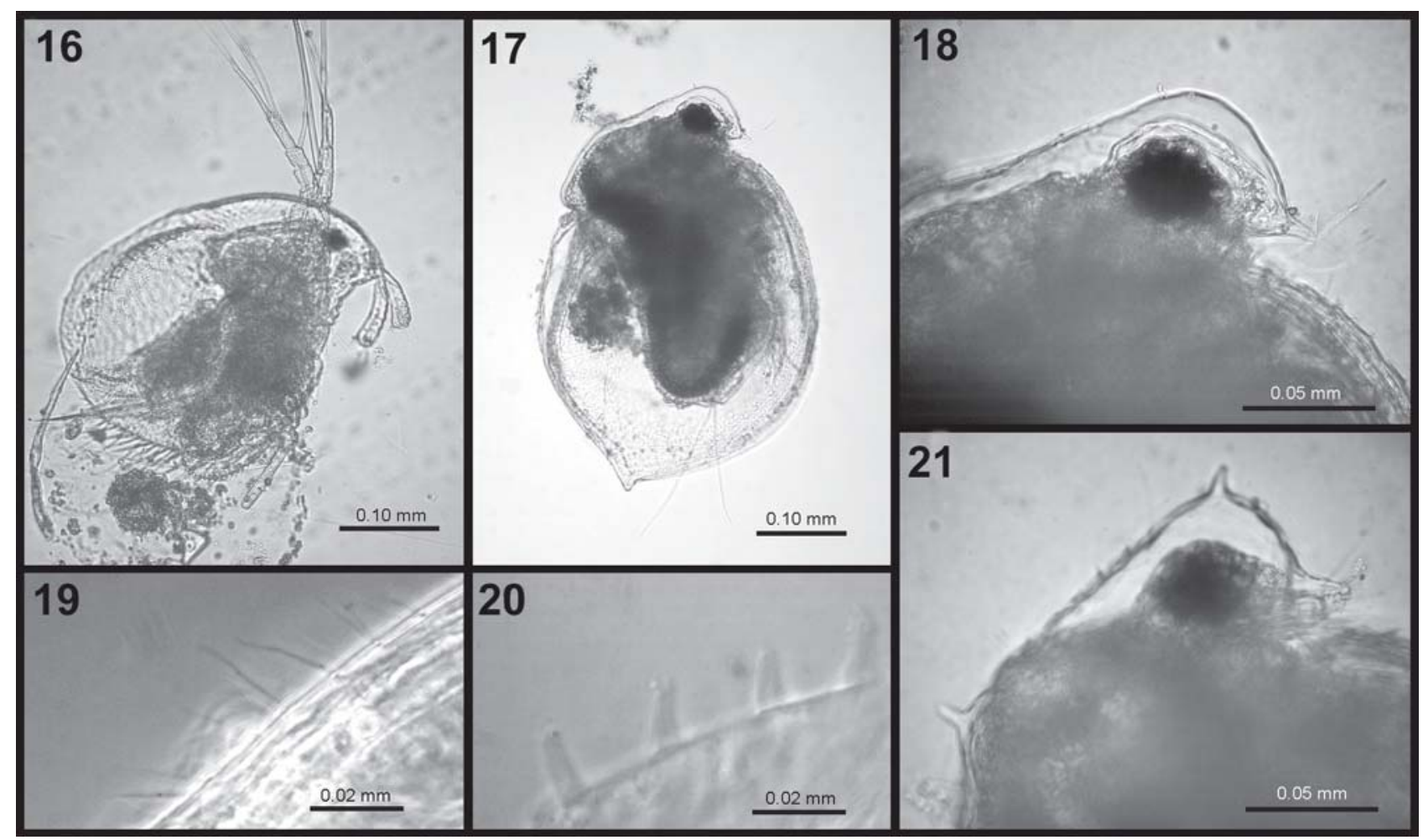

Figures 16-21. Cladoceran species found in water bodies in the Paranã River Valley. (16) Macrothrix squamosa; (17-19) Ceriodaphnia cornuta, fine haired form; (20-21) Ceriodaphnia cornuta, coarse haired form.

ralona dadayi (e.g. ELMOOR-LouREIro 1998), other times as Phryxura dadayi (e.g. Lima et al. 2003). The proposed synonymy between Disparalona Fryer, 1968 and Phryxura Müller, 1867 was rejected by the suppression of the latter name (IczN 2001). Independently of this fact, SMIRNov (1996) suggested the reallocation of this species in the Alonella Sars, 1862 genus until further studies are conducted. In fact, some details of $A$. dadayi morphology suggest that it does not belong to Disparalona, such as its not elongated shape, the better development of the labral plate and absence of the robust seta on gnathobase of trunk limb 3 directed along food groove.

Dumont \& Silva-Briano (2000) discussed the particular characteristics the Alona karua-group (or Biapertura karua-group), concluding that all the species should be transferred to the new genus Karualona, and showing that each one has a restricted distribution to one continent. In Brazil, Karualona mülleri (Richard, 1897) (Figs 12 and 13) was reported from the Pantanal of Mato Grosso (Hollwedel et al. 2003), creating the possibility that previous reports of Alona karua in Brazil were actually this species.

SARS (1901) described Graptoleberis occidentalis (Fig. 14) as a subspecies of Graptoleberis testudinaria (Fischer, 1851). However, the growing evidences of the non-cosmopolitanism of Chydoridae sustain the separation of the two species, already in use by PAGGI (1995).
Alona incredibilis Smirnov, 1984 is distributed throughout the Amazon, and was recently transferred to the Nicsmirnovius Chiambeng \& Dumont, 1999 genus (Kотоv 2003), based on its head pore arrangement, postabdomen and trunk limbs characteristics. The observed specimens (Fig. 15) presented few differences in relation to Nicsmirnovius incredibilis, demanding additional studies to confirm the identification.

Macrothrix squamosa Sars, 1901 (Fig. 16) has been presented as a junior synonym of Macrothrix spinosa King, 1853 (SMirnov 1992). However, evidences of the non-cosmopolitan distribution of species belonging to this genus (SiLVA-Briano et al. 1999, Dumont et al. 2002) raise doubts about the synonymy between M. spinosa, originally described from Australian specimens, and M. squamosa, from the Neotropics. The proposed synonymy was based on superficial similarities, such as the general aspect of the carapace, antennule, and postabdomen. However, the taxonomical revisions of Macrothrix laticornis group (SILVA-Briano et al. 1999) and Macrothrix rosea-triserialis group (Dumont et al. 2002) revealed the importance of the trunk limbs morphology in defining species. Thus, until M. spinosa and $M$. squamosa could be properly studied, it is recommended that they be treated as separate species.

Even so references of the occurrence of Ceriodaphnia cornuta Sars, 1886 (Figs 17-21) exist for almost all Brazilian regions

Revista Brasileira de Zoologia 24 (2): 344-352, junho 2007 
(ELMOOR-LOUREIRo 2000), this is the first record of its hairy morphs from Brazil. According to Berner (1985), such hairy morphs are common and found primarily in littoral habitats. I observed two different patterns: fine haired specimens, generally associated with the rigaudi form (Figs 17-19) and coarse haired specimens (pilosity similar to spines), generally found in the cornuta form (Figs 20 and 21).

The most frequent species were Ilyocryptus spinifer Herrick, 1882, Karualona mülleri, and Alona verrucosa, which were found in more than $50 \%$ of the samples. Latonopsis australis, Chydorus pubescens Sars, 1901, and Ephemeroporus hybridus (Daday, 1905), occurred in $50 \%$ of the samples.

In a few samples, the species Ceriodaphnia cornuta, Moinodaphnia macleayi (King, 1853), Simocephalus acutirostratus-group and Latonopsis australis were particularly abundant, with an estimated relative abundance of nearly $50 \%$ (Tab. II).

Comparison of the communities between wet and dry seasons was only possible in two perennial sampling points (points Itiquira 1 and Macacos 1). A small variation in total richness was verified, but the species composition of the communities were variable (Sørensen coefficient between wet and dry season for point Itiquira $1=0.65$; point Macacos $1=0.40$ ).

Some of the observed species cannot be considered to be truly phytophilous, given that they are typical filter feeders from the planktonic community, this being the case of Diaphanosoma brevireme Sars, 1901, Diaphanosoma spinulosum Herbst, 1967, and Moina micrura Kurz, 1874. These species were found in environments where emergent macrophytes were present, or where open water occurred among the plants, which suggests that their occurrence in the samples was accidental. An alternative hypothesis would be the occurrence of a migration from the limnetic zone, as a strategy to escape from predators, already verified in other species (STANSField et al. 1997).

Higher species richness occurred in environments where submerged macrophytes (points Itiquira 1 and Flores 2), or flooded terrestrial vegetation (point Macacos 2) were predominant. These substrates seem to support a greater variety of microhabitats than emergent or floating macrophytes, favoring exploration by a larger number of species.

The cluster analysis of the sampling points (Fig. 22) indicates the existence of two types of associations of phytophilous cladoceran species in the aquatic environments of the Paranã River Valley. The first association (group A) is related to environments with the predominant presence of emergent macrophytes (points Iaciara 1, Iaciara 2, Macacos 1, and Flores 1), which leads to the occurrence of open water among the substrates (Figs 2 and 3). In this association, a greater number and relative abundance of species of the families Daphniidae and Moinidae (filter feeders) occur than in the second type of association. This is not caused only by the presence of planktonic species, but also by the typical filter feeders from the littoral zone, for example Moinodaphnia macleayi and the Simocephalus species (FrYER 1991).

The second association (group B) occurs in environments

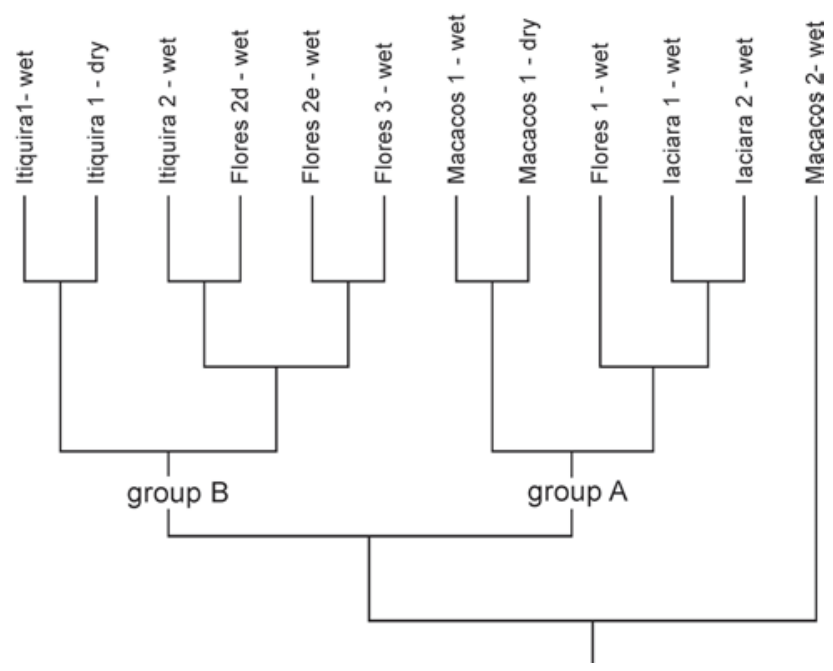

Figure 22. Similarity dendrogram of the phytophilous cladoceran species between the sampling points, during different periods.

that are dominated by submerged macrophytes (Figs 4 and 5), being characterized by a greater richness and elevated relative abundance of the families Chydoridae and Macrothricidae, typically substrate scraper feeders.

The point Macacos 2 is distinguished from the two previous associations (Fig. 22), and it has the highest number of species (Tab. II). The considerable mass of free water between the abundant submerged material (shrubs and tree limbs) created a peculiar and intermediate condition between the two previously described types of environments, which could explain its higher richness.

The results of the cluster analysis, however suggestive, must be considered as preliminary, given that sampling effort was punctual and the abundance of the present taxa was not considered.

\section{ACKNOWLEDGEMENTS}

I thank the biology students from Universidade Católica de Brasília, particularly Rogéria de Alcântara Sodré, Alline Raulino Zeni, and Luciana Barros de Carvalho. To Eduardo Santos for English translation and comments to the manuscript. Financial support: PROBIO/CNPq/MMA.

\section{REFERENCES}

BERNER, D.B. 1985. Morphological differentiation among species in the Ceriodaphnia cornuta complex (Crustacea, Cladocera). Verhandlungen Internationale Vereinigung für theoretische und angewandte Limnologie 22: 3099-3103.

Dodson, S.I. \& D.G. Frey. 2001. Cladocera and Other Branchiopoda, p. 849-913. In: J.H. THORP \& A.P. COVICH (Ed). Ecology and Classification of north American freshwater inverte-

Revista Brasileira de Zoologia 24 (2): 344-352, junho 2007 
brates. San Diego, Academic Press, $2^{\text {nd }}$ ed., XVI+1056p.

Dumont, H.J. 1997. Cladoceran studies: where do we go from here? Hydrobiologia 360: 301-303.

Dumont, H.J. \& M. Silva-Briano. 2000. Karualona n. gen. (Anomopoda: Chydoridae), with a description of two new species, and a key to all known species. Hydrobiologia 435: 61-82.

Dumont, H.J.; M. Silva-Briano \& K.K. Subhash Babu. 2002. A reevaluation of the Macrothrix rosea-triserialis group, with the description of two new species (Crustacea: Anomopoda: Macrothricidae). Hydrobiologia 467: 1-44.

Elmoor-Loureiro, L.M.A. 1998. Branhiopoda. Freshwater Cladocera, p. 15-41. In: P.S. Young (Ed.). Catalogue of Crustacea of Brazil. Rio de Janeiro, Museu Nacional, XVII+718p.

Elmoor-Loureiro, L.M.A. 2000. Brazilian cladoceran studies: where do we stand? Náuplius 8: 117-131.

Elmoor-Loureiro, L.M.A.; L. Mendonç̧a-Galvão \& C. PadovesiFonseCA. 2004. New cladoceran records from Lake Paranoá, Central Brazil. Brazilian Journal of Biology 64 (3A): 415422.

Frey, D.G. 1982. Relocation of Chydorus barroisi and related species (Cladocera, Chydoridae) to a new genus and description of two new species. Hydrobiologia 86: 231-269.

FreY, D.G. 1993. Species of Pleuroxus (Anomopoda, Chydoridae) from subantartic islands and southernmost South America: a partial unrevealing of the Pleuroxus aduncus problem. Hydrobiologia 262: 145-188.

Frey, D.G. 1995. Changing attitudes toward chydorids anomopods since 1769. Hydrobiologia 307: 43-55.

Fryer, G. 1968. Evolution and adaptive radiation in the Chydoridae (Crustacea: Cladocera): a study in comparative functional morphology and ecology. Philosophical Transactions of the Royal Society of London, B 254: 221385.

Fryer, G. 1974. Evolution and adaptive radiation in the Macrothricidae (Crustacea: Cladocera): a study in comparative functional morphology and ecology. Philosophical Transactions of the Royal Society of London (B) 269: 137274.

FrYER, G. 1991. Functional morphology and adaptive radiation of the Daphniidae (Branchiopoda: Anomopoda). Philosophical Transactions of the Royal Society of London (B) 331: 1-99.

Hollwedel, W.; A.A. Kotov \& G.O. Brandorff. 2003. Cladocera (Crustacea: Branchiopoda) from the Pantanal (Brazil). Arthropoda Selecta 12 (2): 67-93

IczN (International Commission of Zoological Nomenclature). 2001. Opinion 1967 - Disparalona Fryer, 1968 (Crustacea, Branchiopoda): conserved. Bulletin of Zoological Nomenclature 58 (1): 68-69.

Korovchinsky, N.M. 1992. Sididae and Holopedidae. Amsterdam, SPB Academic Publishing, IV+82p.

Korovchinsky, N.M. 1996. How many species of Cladocera are there? Hydrobiologia 321: 191-204.
Koтov, А.А. 2003. Notes on Aloninae Dybowski \& Grochowski, 1894 emend. Frey, 1967 (Cladocera: Anomopoda: Chydoridae). 1. Translocation of Alona incredibilis Smirnov, 1984 to the genus Nicsmirnovius Chiambeng \& Dumont, 1999. Arthropoda Selecta 12 (3-4): 167-170.

Kotov, A.A.; H.J. Dumont \& K. Van Damme. 2002. Redescription of Ilyocryptus sarsi Stingelin, 1913. Hydrobiologia 472: 207222.

Lima, A.F.; F.A. LanSAC-TôHA; L.F.M. VelHo; L.M. BinI \& A.M. TAKEDA. 2003. Composition and abundance of Cladocera (Crustacea) assemblages associated with Eichhornia azurea (Swartz) Kunth stands in the Upper Paraná River floodplain. Acta Scientiarum: Biological Sciences 25 (1): 41-48.

MAdDison, W.P. \& D.R. MADDISON. 1992. MacClade: analysis of phylogeny and character evolution, Version 3.04. Sunderland, Sinauer.

Margaritora, F.G.; M. Bazzanti; O. Ferrara; L. Mastrantuono; M. Seminara \& D. Vagaggini. 2003. Classification of the ecological status of volcanic lakes in Central Italy. Journal of Limnology 62 (Suppl. 1): 49-59.

Nogueira, M.G.; D.G. George \& A. Jorcin. 2003. Estudo do zooplâncton em zonas litorâneas lacustres: um enfoque metodológico, p. 83-127. In: R. HenRy (Ed.). Ecótonos nas interfaces dos ecossistemas aquáticos. São Carlos, Editora Rima, VIII+349p.

Orlova-Bienkowskaja, M. 2001. Cladocera: Anomopoda (Daphniidae: genus Simocephalus). Leiden, Backhuys Publishers, VIII+128p.

PAGGI, J.C. 1995. Crustacea - Cladocera, p. 909-951. In: E.C. LopReTto \& G. TELL (Eds). Ecossistema de aguas continentales: metodologias para su estudio. La Plata, Ediciones Sur, Tomo III.

SARS, G.O. 1901. Contribution to the knowledge of the freshwater Entomostraca of South America. Part I. Cladocera. Archiv for Mathematik og Naturvidenskab 23 (3): 1-102.

Silva, L.A. \& A. SCARIOT, 2003. Composição florística e estrutura da comunidade arbórea em uma floresta estacional decidual em afloramento calcário (Fazenda São José, São Domingos, GO, Bacia Do Rio Paranã). Acta Botânica Brasílica 17 (2): 305-313.

Silva-Briano, M.; N.Q. Dieu \& H.J. Dumont. 1999. Redescription of Macrothrix laticornis (Jurine, 1820) and description of two new species of the M. laticornis-group. Hydrobiologia 403: 39-61.

SINEv, A.Y. 1998. Alona ossiani sp. n., a new species of the Alona affinis complex from Brazil, deriving from the collection og G. O. Sars (Anomopoda: Chydoridae). Arthropoda Selecta 7 (2): 103-110.

SINEv, A.Y. 2001a. Redescription of Alona glabra Sars, 1901, a South American species of the pulchella-group (Branchiopoda: Anomopoda: Chydoridae). Arthropoda Selecta 10 (4): 273280.

Sinev, A.Y. 2001b. Redescription of Alona iheringi Sars, 1901 (Chydoridae, Anomopoda, Branchiopoda), a South American 
species related to A. rustica Scott, 1895. Hydrobiologia 464: 113-119.

Sinev, A.Y. \& W. Hollwedel. 2002. Alona brandorffi sp.n. (Crustacea: Anomopoda: Chydoridae) - a new species from Brazil, related to A. verrucosa Sars, 1901. Hydrobiologia 472: 131-140.

Sinev, A.Y.; A.A. Kotov \& K. van Damme. 2004. Morphology of a Neotropical cladoceran Alona dentifera (Sars, 1901), and its position within the Chydoridae Stebbing, 1902 (Branchiopoda: Anomopoda). Arthropoda Selecta 13 (3): 99-107.

Smirnov, N.N. 1992. The Macrothricidae of the world. Amsterdam, SPB Academic Publishing, VIII+143p.

SMIRNOv, N.N. 1996. Cladocera: the Chydorinae and Sayciinae (Chydoridae) of the world. Amsterdam, SPB Academic

Received in 21.VI.2006; accepted in 30.IV.2007.
Publishing, VI+197p.

Stansfield, J.H.; M.R. Perrow; L.D. Tench; A.J.D. Jowitt \& A.A.L. TAYLOR. 1997. Submerged macrophytes as refuges for grazing Cladocera against fish predation: observations on seasonal changes in relation to macrophyte cover and predation pressure. Hydrobiologia 342/343: 229-240.

SWOFFORD, D.L. 1999. PAUP: phylogenetic analysis using parsimony and other methods, version 4. Sunderland, Sinauer. TakedA, A.M.; G.M. SouzA-Franco; S.M. Melo \& A. Monkolski. 2003. Invertebrados associados às macrófitas aquáticas da planície de inundação do alto rio Paraná (Brasil), p. 260.243. In: S.M. Thomaz \& L.M. Bini (Eds). Ecologia e manejo de macrófitas aquáticas. Maringá, Universidade Estadual de Maringá, 341p.

Revista Brasileira de Zoologia 24 (2): 344-352, junho 2007 